\section{“Migrants Are Splendid Types": The "Beautiful Balts" Megamarketing Campaign to Boost the Reception of Displaced Persons in Australia after World War II}

\author{
Jayne Krisjanous, ' ${ }^{(\mathbb{D}}$ and Djavlonbek Kadirov' ${ }^{\prime}$
}

\begin{abstract}
Human migration is often a result of flight from post-conflict socio-economic disintegration, where dysfunctional marketing systems exacerbate the suffering of people. Despite the potential trauma and disruption incurred, a move away to systems perceived to be better are favored. Using a historical research approach, this article focuses on the end of World War II that heralded an unprecedented humanitarian crisis involving millions of displaced persons, marshalled in Displaced Persons' (DP) Camps. This investigation focuses on the "Beautiful Balts" megamarketing campaign in Australia, the promotion of a handpicked consignment of DPs from the Baltic States of Lithuania, Latvia and Estonia to host-to-be communities, in order to satisfy the economy's growing need for fresh industrial labour input. The authors argue that this campaign was crucial in dismantling the "white only" frame through the use of the hitherto undocumented process of frame demystification. This campaign set the stage for the opening up of Australia to greater numbers of post-WWII DP migrants from different ethnicities and fundamental changes to beliefs and practices that configured Australian marketing systems of the day.
\end{abstract}

\title{
Keywords
}

macromarketing, marketing systems, Beautiful Balts, displaced persons, closed systems, megamarketing, historical research in macromarketing, framing process, demystification

\section{Introduction}

Devastated marketing systems in post-conflict societies spur many from these societies to emigrate (Sredl, Shultz, and Brecic 2017). Host countries already overburdened by the mass arrival of immigrants in recent years face a major challenge when suddenly faced with resettling refugees from conflict areas (Hatton 2017).

Indeed, an "anti-immigration" frame is gaining momentum in many countries. This frame is evidenced by 1) the Trump administration's anti-immigrant rhetoric in the US, 2) the Hungarian Prime Minister's "anti-Soros" bill (Reuters 2018), and 3) the former Australian Prime Minister Tony Abbott's "revelation" that increasing immigration is the direct cause of a host of societal problems including quality-of-life issues (The Guardian 2018).

Australia's policies for incarcerating asylum seekers (or those arriving in Australia without a visa) on offshore sites such as Manus Island or Nauru is regarded by many as excessively harsh. Some critics term these policies as a human rights catastrophe (Davidson 2016). These policies are viewed by some as having detrimental impacts on Australia's democratic and legal systems, its regional relationships and the international system of protection of refugees and asylum seekers (Bem et al. 2007; Fleay and Hoffman 2014).

Under the title "We must Rediscover the Humanity of 1945", Aaronovitch (2015) reminds readers of images of "lorries full of dead Syrians in a layby in Austria, ferries full of refugee-migrants chugging from Lesbos to Piraeus, thousands of exhausted people barrier-crashing the platforms at Budapest station, a tiny boy with his shoes on, washed up dead on a beach near Bodrum" (The Times, September 3, 2015). Even today, host societies face a challenge of refocusing their marketing institutions toward humanism and rediscovering wisdom in humane co-existence (Kadirov and Varey 2014).

\footnotetext{
'School of Marketing and International Business, Victoria University of Wellington, Wellington, New Zealand

\section{Corresponding Author:}

Jayne Krisjanous, School of Marketing and International Business, Victoria University of Wellington, Wellington, New Zealand.

Email: Jayne.Krisjanous@vuw.ac.nz
} 
Looking back, the "Beautiful Balts" campaign, an initiative taken by the Honourable Arthur Calwell, the Australian inaugural Immigration Minister 1945-49, to introduce Australia to a new type of migrant and labour force, is only a small part of the WWII displaced persons (DPs) story, yet significant for understanding how change can be enacted in marketing systems. The promotion of a handpicked consignment of "Balts" (those from the Baltic States of Lithuania, Latvia and Estonia), from World War II (WWII) displaced persons camps (DP camps) mainly throughout Germany's Occupied Zones, was to herald the beginning of changes to dominant economic, political, legal and socio-cultural frames that would gradually transform Australia's static and predominantly "privilege-based" marketing systems. The Beautiful Balts episode is referenced within other disciplinary literatures, particularly migrant and historical work (for in-depth historical analysis of Australia's post WWII DP history see Persian 2015, 2017), and forms a significant part of Australian immigration history, profoundly influencing the lives of generations to come. Curiously however, the macromarketing aspects of the strategy behind the Beautiful Balts campaign has been overlooked by marketing academe to date. Yet at its core is unintentionally intelligent marketing, not of a typical micro-managerial type, but as a megamarketing framing intervention that changed the institutional dynamics of aggregate marketing systems of the time.

This study addresses the call set out in this special issue for reflection upon the past to examine 1) marketing systems, and 2 ) how changes or tipping points have been "strengthened or altered in order to benefit society" (Alderson 1957) (cited in Wooliscroft and Ganglmair-Wooliscroft 2017). This exploration of the Beautiful Balts campaign contributes to historical macromarketing research from a marketing systems perspective. In particular, we explore how this megamarketing initiative solved the immigration conundrum of the day, changing the way marketing systems operated in Australia at the time, through the injection of large numbers of new migrants, as a new action fields' force. This study aims at contributing to the broad programmatic purpose of understanding sources of stability and change in marketing systems (Fligstein and McAdam 2012; Layton 2015). Sredl, Shultz, and Brecic (2017) suggest that over the past five decades of research into marketing systems, most research has been aimed at understanding, changing, and/or improving systems by concentrating on existing sites. Here, "established social, political, ecological, economic systems exist in various forms to deliver goods and services to consumers and communities" (p. 3), and therefore, are focused on best practice. Sredl, Shultz, and Brecic (2017) turn their attention to exploration of marketing systems and community in post-conflict sites, where "states have disintegrated or failed, and marketing systems have been affected by a dramatic structural break" (p. 3).

Our historical case study examines a context where the aggregate national marketing system in focus was not fatally fractured per se, but acted as a host that "absorbed" the negative spill-over of other fractured marketing systems. In order to do this, we focus on the use of megamarketing as a framing strategy that re-framed the migrants as the holders of valuable endowments for an existing marketing system, while weakening the dominant "white only" frame (upheld by The White Australia policy and essentially reflecting Australia's desire to be "British white" only [Tavan, 2004]). Notably, megamarketing is not a simple extension of micromarketing tools, which some historical research in marketing undertaken to date assumes (see Thomas 2016), but at a mass scale. Megamarketing is based on internal changes, i.e. re-structuring of institutional logics, so that a marketing system opens up to progressive changes including the intake of entropy minimizing inputs. Here we highlight how the potential benefits from an influx of substantial endowment, workers willing to work to meet increasing infrastructure development needs, was jeopardized by institutional disorder. Such disorder included a potentially hostile environment, a lack of prior knowledge within the new worker group of the idiosyncrasies of the marketing system they would enter, along with their little market power. Therefore, market transformation depended largely on novel strategies by the Australian Government to open up the market.

To make clear the contributions of this work, we categorise them into three main strands. First, we examine and extend macromarketing historical analysis through case study of a significant post WWII event, neglected by marketing to date. Scholarly historical attention of the post-WWII period is often considered secondary to the tumultuous events leading up to and during fighting. However, it is very much during the first few years post WWII that the disarray of national, societal and commercial systems created a "chaos" in Europe, unprecedented in modern history (Lowe 2013). It is also this postwar period that gave rise to many of the institutions and disciplines that today continue to deliver coordinated international response and aid to refugees from conflict and is also credited with the emergence of international human rights norms (Ashutosh and Mountz 2011). The Beautiful Balts campaign offers valuable insights into marketing systems and critical points that force change. Second, the application and further development of a megamarketing framework and framing process lens adds a significant theoretical contribution to an understanding of marketing systems. We document a unique framing process, not discussed hitherto in the extant literature, which we label as "demystification".

Finally, although the context is historical, it has wider societal implications. While the population and workforce needs of host countries are vastly different today from 1945, it was in the multi-nation response to the post WWII DP problem that many of the key concepts and tools for addressing the migration conundrum were born. Although the Beautiful Balts campaign is examined here for its merit in opening up the Australia's marketing systems for the benefit and goals of the incumbent government, it also served as a catalyst for Australia to demonstrate a humanitarian disposition and contribute to a successful international programme to clear the post WWII DP camps. In this way, this topic contributes by discussing an important societal issue, the like of which macromarketing embraces. 
The remainder of this article is as follows: first, the conceptual framework that underpins our research is introduced. Second, the methods used for the study are outlined. Following this, the historiography of the Beautiful Balts campaign and subsequent continued WWII DP immigration to Australia is described. The Australian Government's rationale for acceptance of European DPs contra to the seemingly rigid immigration policies of the day are explained within the post-war context of Australia. We then progress, as discussion, to draw together the macromarketing conceptual lenses selected to explain the impact WWII DP migration to Australia, initiated by the Beautiful Balts campaign, had on marketing systems.

\section{Conceptual Framework}

This study extends a proposition that the human factor is an important consideration in understanding how marketing systems form, grow and change. The conceptual insights used to underpin our work are drawn from the MAS framework (Layton 2015), action fields theory (Fligstein and McAdam 2012), open/closed systems theory (Reidenbach and Oliva 1981, 1983), and megamarketing (Humphreys 2010; Kotler 1986). We refer to these theories to explain how the aggregate Australian marketing system gained an uncharacteristic receptiveness to supposedly peregrine human resources and alien endowments due to a well-thought megamarketing initiative. The key theories are outlined below.

\section{MAS Theory}

Here we combine the Mechanism, Action, Structure (MAS) framework (Layton 2015) and open systems theory (Reidenbach and Oliva 1981, 1983) to explain why marketing systems may turn into "closed" markets. MAS theory posits that marketing systems are the product of human action. Specifically, the MAS framework advocates a view of marketing system participants interacting with each other based on different social mechanisms that in the long term engender distinctive stable structures. According to Layton (2015), the locus of human action in marketing systems is action fields. Action fields represent meso-level interactive spaces where marketing system actors not only vie for perceived advantage, but also cooperate based on shared understanding of purpose, rules, and sense of belongingness (Fligstein and McAdam 2012). Within action fields, stability begins to form as actors learn to meaningfully relate to each other as well as outsiders, most often developing institutional symbolism about how different actors could potentially contribute to the maintenance and perpetuation of a familiar order (Layton 2015). Applying Fligstein's (2001) classification, Layton divided marketing system actors into three broad groups: incumbents, challengers, and governance units. While incumbents dominate the system and work to preserve stability, challengers, while occupying niche/entrepreneurial positions, experiment with alternative institutional logics in order to modify the order taken for granted. Governance units (e.g. regulatory agencies) act to enforce established rules and conventions. As the extent of specialization increases, actors become aware of own and others' differential capabilities, skills and resources which are referred to by Layton as endowments.

Incumbents, guided by self-interest, strive to effect favourable changes in the purpose, structure and governance of the system (Fligstein and McAdam 2012), thereby introducing mechanisms through which endowments are carefully screened. Stability requires filtering mechanisms through which only meaningful endowments as well as endowment agents/owners are allowed in. As a consequence, the marketing system may increasingly transform into a partially closed system (Reidenbach and Oliva 1981, 1983), where its interactions with other action fields is strictly regulated. Reidenbach and Oliva (1981) apply the principles of General Living Systems theory and the laws of thermodynamics to argue that closed systems paradoxically move toward entropy (i.e. a state of disorder) in the long-term. They argue that, contrary to incumbents' perceptions, dynamic order can only be maintained if the system can ensure entropy-compensating inputs from the environment. Extending these views to the institutional context of marketing systems, we argue that this is a matter of maintaining relevance in the face of fast changing environmental conditions. Rigid system structures tend to react to environmental changes slowly, while creating an increasing extent of misfit to new conditions. Perhaps, here lies the dilemma of institutional change in a marketing system: as actors pursue their sense of "order" by limiting "alien" inputs, they might develop excessively rigid governance structures, which in turn may contribute to gradually increasing disorder.

\section{Megamarketing and Framing Processes}

The phenomenon of closed marketing systems was recognized by Kotler (1986), albeit from a firm's perspective seeking an entry to new markets. Kotler called such market systems "blocked markets". He reasoned that incumbent actors (e.g. businesses, consumers, suppliers, regulatory agencies, labour unions, banks) can block a market by erecting tangible and intangible barriers for entry. Kotler proposed a new approach, megamarketing strategy, which would involve "the strategically coordinated application of economic, psychological, political, and public relations skills to gain the cooperation of a number of parties in order to enter and/or operate in a given market" (Kotler 1986, p. 117). Extending Kotler's definition to the context of new market creation and thus the domain of macromarketing, Humphreys (2010) repositioned megamarketing as a social process of market building that involves attempts to structure the cultural, social, and legal facets of a marketing system so that opportunities for new developments and innovations arise. As a side-note, the review of relevant literature indicates that megamarketing is closely related to the macro-social marketing perspective. Although the former focuses on managerial action, while the latter on social activism, both perspectives draw on the work in the area of institutional logics (Scott, 2014). Both emphasize the centrality of 
"meaning work", i.e. the mobilization of meanings and symbolism in marketing systems (Benford and Snow 2000; Kadirov and Varey 2011). The megamarketing approach calls for examining cultural-cognitive systems to enhance the legitimacy of a desired change (Humpreys 2010), while the macro-social marketing perspective calls for the analysis of cultural-moral institutional norms to institutionalize a behavioural change (Kennedy 2016). Yet, both perspectives would agree that framing processes are at the heart of meaning work, and thus, marketing systems dynamics related to institutional logics (Benford and Snow 2000).

Cultural frames refer to common cognitive structures which underscore the ways market system actors "locate, perceive, identify, and label" events they experience in order to make sense of them (Goffman 1974, p. 21), whereas "framing process" refers to active, purposeful, and evolving initiatives of meaning construction and change (Benford and Snow 2000). Benford and Snow indicate that the result of framing process is a "collective action frame", that is, meanings that facilitate action in a specific context while promoting the agent's interests. Further, they argue that for collective action frames to be effective they must have a strong resonance with the target population. The strength of resonance depends on a) frame consistency, i.e. it is free of contradictions; b) empirical credibility, i.e. close fit between the frame and real events; and c) credibility of frame authors.

Humphreys (2010) outlined four framing processes as the core of megamarketing strategy: amplification, extension, bridging, and transformation. Benford and Snow (2000) call these processes "frame alignment", since these processes help to align the agent's perspective with that of the market. As Humphreys (2010) observes, the gambling industry in the US used different framing processes to legitimize its business model. The industry made use of frame amplification, embellishment of selected meanings, through highlighting the "fun" aspect of gambling with a goal of de-emphasizing a more common negative frame related to "addiction". Amplification is also linked to "counter-framing" which involves the selection and propagation of alternative favourable frames in order to symbolically militate against meanings proposed by social activists (Benford 1993; Benford and Snow 2000). Frame extension refers to the process of extending meanings for a phenomenon under focus beyond its commonly accepted meanings. Extension is evident in the gambling industry's efforts to augment the core meaning of "casino" with meanings that support the perception of "allinclusive entertainment resort" (Humphreys 2010). Frame bridging process is based on pairing completely distinct meanings, such as the gambling industry's attempts to associate gambling with sustainability (Humphreys 2010). Frame transformation is defined as the process of creating new meanings (Benford and Snow 2000). Although Humphreys (2000) finds no evidence of frame transformation in the US gambling industry, there is evidence that it has been used by some organizations (Benford and Snow 2000; Berbrier 1998). Berbrier (1998) analyzed the rhetoric of "new racism" and found several framing processes at work. Specifically, he finds that white supremacists employ alternative frames such as "love", "pride, and "heritage" to attain greater legitimacy among potential constituents. Also, a unique case of frame transformation is used: the movement attempted at the meaning reversal of the common frame "white supremacy" by positioning itself as being "equal" to other minority groups in its attempts to preserve its heritage.

Collective action frames are continually contested among various actors (Benford and Snow 2000). To weaken dominant frames, actors use "counterframing" which refers to "[attempts] to rebut, undermine, or neutralize a person's or group's myths, versions of reality, or interpretive framework" (Benford 1987, p. 75). Internally, counterframing results in "framing disputes", disagreements among system actors on how the dominant frame should be exactly formulated in both discourse and action. Although the existing literature provides a comprehensive description of counterframing tactics (Benford and Snow 2000), the main focus appears to be on direct confrontation. To our knowledge, there is no discussion of a (counter)framing process that aims at delegitimizing the established action frame through meticulously applying the frame in practice to expose its absurdity. "Demystification" is an idiomatic term that we use to express an ideological struggle to publicly expose and delegitimize entrenched collective action frames through not only unmasking but also trivializing, profaning, and desacralizing its concealed mystique.

We present demystification as a conceptual proposition. It is through the case study provided here that it may be directly observed. It involves a paradoxical reversal whereby a deceptively outward support for the frame, ranging from publicly promoting the frame to applying its principles in practice, is in fact designed to poke holes in the rationality and sensibleness of the whole ideology. Demystification can be further explained as a process that undermines the deep symbols foundational to a "truth" or tightly held universal belief system (here Australia's immigration policies of the day). Deep symbols described originally by Farley (1996) are feelings so basic that they might be taken for granted, often then concealing elusive qualities and ambiguities in a "master narrative that reflexively identifies and defines social action in human communities" (Anderson 2003, p. 30). Farley (1996) offers different examples of deep symbols: education, beauty, reality, rights, nature, freedom, community, and justice. Smyth (2009) collates Farley's (1996) description of a deep symbol, as used in theology, to comprise attributes "whereby they 1). function as a moral compass, exercising a normative influence; 2) hold a power to enchant or allure 3) have been subject to historic change and interpretation - so it is relative rather than absolute; 4) when absolutized, it betrays signs of fallibility and liability to moral corruption. Like any word of power, it may evoke transcendent mystery..." (p. 231). By weakening the strength of deep symbols that underpin the belief system critical to supporting the collective action frame, the latter is demythologised or demystified. An eventual outcome of this is that the collective action frame is revealed to be no longer relevant. The existing evidence for this in marketing systems seems to be anecdotal. For example, a similar technique was 
Table I. Framing Processes.

\begin{tabular}{|c|c|c|c|}
\hline $\begin{array}{l}\text { Framing } \\
\text { Process }\end{array}$ & $\begin{array}{l}\text { Megamarketing } \\
\text { Approach }\end{array}$ & Description & Mystique/Deep Symbolism \\
\hline Amplification & Legitimization & $\begin{array}{l}\text { Highlighting, clarifying, embellishing selected meanings } \\
\text { that serve the interests of the frame author }\end{array}$ & The approach further mystifies the frame \\
\hline Extension & Legitimization & Augmenting, expanding, developing the core meaning & $\begin{array}{l}\text { The approach expands the frame's } \\
\text { abstraction. Its mystique is enhanced. }\end{array}$ \\
\hline Bridging & Legitimization & $\begin{array}{l}\text { Combining several unrelated meanings to construct } \\
\text { a new composite meaning }\end{array}$ & $\begin{array}{l}\text { The approach attempts to clarify one source } \\
\text { of mystique by appealing to another. }\end{array}$ \\
\hline Demystification & De-legitimization & $\begin{array}{l}\text { Exposing (intentionally or unintentionally) the absurdity of } \\
\text { the old entrenched meaning by applying it in practice }\end{array}$ & The approach demystifies the frame. \\
\hline
\end{tabular}

used by Stetson Kennedy to effect a significant damage to the expected post-war revival of the Ku Klux Klan movement (Kennedy 2011). When most neutralizing measures against the movement seemed to have failed, Kennedy and his associates decided to publicize the secret rules, codified language, passwords, and rituals of the movement in the form of a children's radio broadcast (Levitt and Dubner 2006). Many adults, observing their children playing the Superman against the Klan game learned from this radio broadcast, realized the extreme absurdity the movement harbours. A summary table outlining framing processes is shown in Table 1 .

\section{Method}

This study applied case study historical analysis and marketing systems research method common within macromarketing (Sredl, Shultz, and Brecic 2017). Data collection involved recording the chronology of the movement of Baltic DPs to Australia. A periodization of 1945-1954 was chosen as this covers the main Baltic DP movement to Australia and allowed us to situate the narrative of the Beautiful Balt campaign best. To gain insights, both contemporaneous (historical) and more contemporary articles and documents were sourced and analysed. Many Australian archival centres, such as The National Archives of Australia (NAA) hold information related to WWII Displaced Persons (and wider immigrant entry) and historic government immigration policies. Many of these are offered in digitalised formats that make records very accessible to the researcher. Digitalized newspapers on websites such as TROVE (National Library of Australia) were also a valuable source of reported information and to capture the "mood" of the day. Contemporaneous sources retained as relevant included scholarly articles (11), archival government documents and records (18) and newspaper articles (24) available through archival centres. Numerous other pieces scanned were of great background reading interest, but not considered directly material to development of this work. Recent works by authors were also sourced for their insights (see for example Persian 2015, 2017), whose publications are based on extensive PhD work in the area of DP migration to Australia. In particular, resources that gave voice to the reflections of DPs set down through retrospective interviews and memoirs were invaluable. In addition, one of the authors of this article is a first generation descendent born to a Balt (Latvian) DP accepted to Australia. This allowed delving in personal archives and documentation for leads to sources where archival material might be available.

Once the chronology was laid out, constant comparative analysis was employed where authors compared archival documents against each other to authenticate analysis of events (Eisenhardt 1989; Eisenhardt and Graebner 2007). This led to debate on what could be considered most insightful for what was being observed in a macromarketing context and allowed multiple sources of information to diverge on a single explanatory frame. As the work progressed, the modern day migrant situation was brought into focus and rigorous analysis and author discussion as to the fit and explanatory contribution of demystification in today's world was progressed. This enabled a "circling back" to solidify the work and its contribution to contemporary macromarketing theory.

We now present the Beautiful Balts story in order to showcase our proposition.

\section{The Beautiful Balts and DP Migration to Australia}

\section{The Problem of Displacement at the End of WWII}

Even before the end of WWII in August 1945, an unprecedented humanitarian crisis was emerging, with around twelve million of Europe's population displaced and "on the move" or outside of their countries (Berger 1947). This group were to become known as Europe's WWII Displaced Persons (DPs). Whilst most eventually made their way home, either by themselves or through the efforts of newly formed external agencies such as The United Nations Relief and Rehabilitation Administration (UNRRA) (Fox 1950) and then its successor the International Refugee Organisation (IRO), a significant percentage of DPs either could not return to their original countries due to border changes, or resisted repatriation. For them, even if their country still existed at the end of the war, returning home was not considered a viable option. For some, the return home realised the total loss of all family and community and ongoing fear of discrimination (felt in particular by the Jewish DPs who 
had been in concentration camps), whereupon they returned back to the camps (Gemie, Humbert, and Reid, 2012).

In the case of those from the Baltic States, a large majority had evacuated their homeland during or at the end of the war ahead of the approaching Soviet occupation, refusing to stay and live under Soviet rule (Berger 1947). Essentially not strictly meeting the criteria needed to attain DP status, their personal situation might have been precarious. Forced repatriation to their home countries at the request of the now occupying Soviet regime was rejected by repatriation authorities, based on the United States (US), European Parliament and United Nations Humans Rights Council position that the Soviet annexation occupation of the Baltic States, under the arrangements of the Soviet-Nazi 1939 Molotov-Ribbentrop Pact, was illegal. This stance thus afforded Balts DP status and the protection that offered (Cohen 2008).

Assembly centres for DPs were located in four zones administered by the Allies: US, Great Britain, Russia (Soviet Union), and France. There were 700 camps throughout these zones, with DP populations in each varying between 500 to 6,000 (see Figure 1). The first camps opened in May 1945, configuring military barracks, hotels and ex-concentration camps (including Belsen). Quasi-military design made facilities such as concentration camps well suited for the mass control of people and initial processing and quarantine. As first, the situation was chaotic, this post WWII period aptly nicknamed by some "sorting out the perpetual muddle" (Shephard 2010). Overtime, and where ethnic groups were able to regroup and cluster, self-governing systems emerged comprising communication channels, schools, entertainment, cultural activities and in some cases, black markets (Carpenter 2017; Gemie, Humbert, and Reid 2012). These systems, as cultural production centers, were valuable as being relocatable structures they were often rolled out intact in countries of resettlement, providing invaluable cultural connections and governance. This worked particularly well if sufficient numbers were living in the same areas post resettlement, usually large towns and cities.

The initial key roles of UNRRA were to provide shelter (relief) and expedite/facilitate repatriation to home countries. However, for the bulk of longer stay camp occupants (including the Balts), a major role, particularly under its successor IRO, became the facilitation of international efforts to organize resettlement to those countries who agreed to accept DPs, and were in a position to do so. For host countries offering refuge to a large number of displaced persons, the sheer technicalities of accommodating such numbers could be daunting (Copland 1951). In particular, for the existing population of host countries, the needs and potential problems that might arise from large numbers of new arrivals could cause tensions exacerbated by perceptions of difference.

Several host countries (England, US, Canada, Australia, New Zealand and parts of South America) accepted a quota of DPs for resettlement. Emigrations occurred from 1947 till the late 1950s, where only those considered difficult placements (those who were sick, elderly, insane, some inmates of concentration camps deemed unfit or unsuited for resettlement)

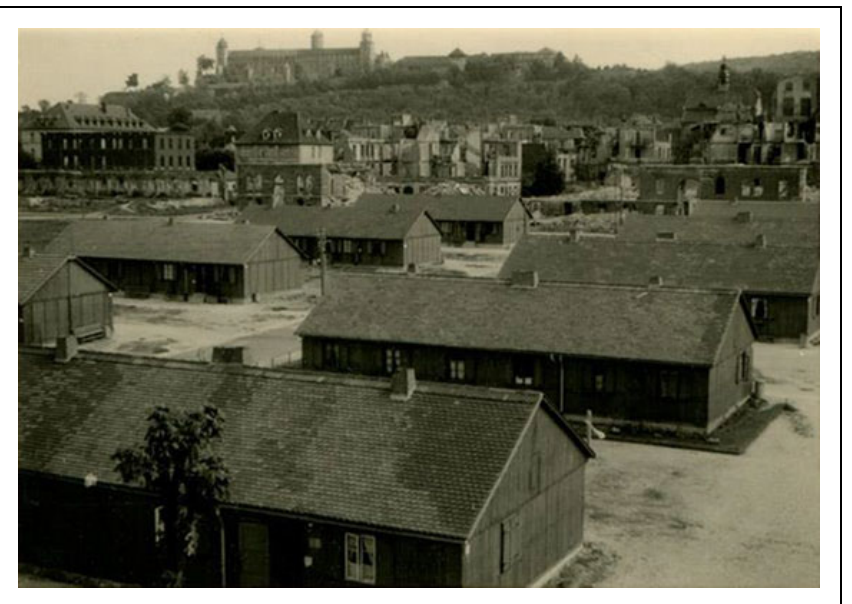

Figure I. Würzburg Latvian DP camp. Source: National Archives of Latvia, LVA, 2335.

remained (Shephard 2010). While the acute humanitarian need was recognised, the potential for a relatively cheap labour supply was undeniably attractive, particularly in light of the aftermath of conflict, and in many cases, a depleted labour force realised from military losses from both WWI and II. In Australia, declining birth rates, as seen in the census data in the decades preceding the war, and depletion of male workers from WWI meant a shortage of male workers available for manual work (Storer 1984).

\section{Australia's Response to the DP Crisis}

At the same time, some circles in the post-war Australian government recognised that change was needed in order to both survive and prosper into the future. The recognition of a changing world, the threat of communism and the approaching Cold War, along with its own position within the Asia-Pacific defined the need for major infrastructure and defence growth (Persian 2015). Hence, actions fields focusing on the need for fresh labour input has slowly emerged. The realization that change was needed was an internal force that led to the recruitment of some governance units into a pro-change camp. Here Calwell (as Immigration Minister), with the agreement of the Prime Minister, Ben Chifley, as agents understood that the desired change could only be achieved through a rapid and significant inflation of its population. In 1945, the population of Australia was seven million. Of those, only one million had been born outside of Australia.

The incumbent attitude toward immigration, and the orthodox institutional logic of the "value" of immigration were reflected in the government policies of that period. Since Australia's beginning as a convict colony, and then planned growth through strictly controlled voluntary immigration, a "mainly British" Australia had been constructed. The government's rigid white (sic) only orientation, made implicit within the 1901 Immigration Restriction Policy, and in additional policies that became collectively known as the "White Australia" 
policy, had worked to deliver a population profile desired by accepting immigration mainly only from Great Britain (Tavan 2004). Post WWII, prospective British emigrant popularity in an Australian strategy designed to attract British migrants through assisted migration was achieving poor success, with insufficient numbers taking up the offer to bring about any real impact on population growth (Tavan 2004). It became clear that the imperative of substantive population growth would not be achieved through continuing to adhere to the immigration policies of old. It was recognised that a dismantling of a "white only" policy might be controversial, particularly when the need to increase population was made manifest and therefore accepted out of necessity, but not as Tavan (2004) puts it, removed from the hearts and minds of the people.

A complete frame transformation was required, as the discourse of immigration switched from "White Australia" to one of "Populate or Perish". The Populate or Perish slogan, aimed at serving as a persuasive reason why, was the means through which Australian citizens could be exposed to a new immigration logic. This was made clear by Calwell, in the rhetoric used to address the Australian population. This warned of "potentially lethal dangers of a communist China and resurgent Japan" (The Mercury 13 October 1949 p. 1) and that "Australia would not be held by ourselves or our descendants as a citadel of people of European descent. Our entire heritage will vanish before Asiatic Power" (ibid, p. 1). Positioning Australia as indefensible against such forces was used as a means to commence the disruption of the entrenched frame that had prevailed for decades.

Direct frame transformation had its perils as it would endanger the credibility of frame authors (due to them challenging the prevailing deep symbols) and perpetuate the questions of empirical credibility (What if the population realizes that the claims were exaggerated?). However, the benefits were clear. The change champions reasoned that the DP crisis provided the opportunity by which Australia could advance population growth rapidly, inflate its labour resource through relatively low cost means, and at the same time assert the country's humanitarianism to a global audience. Instead of directly challenging the "white only" frame or attempting to construct a new one, they devised an approach that would exploit the strength of the existing frame. The approach did not transform, amplify, extend or bridge the old frame. It was based on simply putting the old frame into practice in a literal sense. This approach would be particularly effective if the "best types" could be acquired (Persian 2015). In 1947, Australia signed an agreement with the IRO. The IRO paid for a portion of the transportation costs (by ship) and the Australian Government the rest. In return, DPs were to sign a two-year contract for indentured and approved employment and in a region approved of by the government (Murphy 1952).

\section{The Beautiful Balts Campaign}

The Beautiful Balts campaign was simple in its design, yet effective as a means of introducing the Australian population

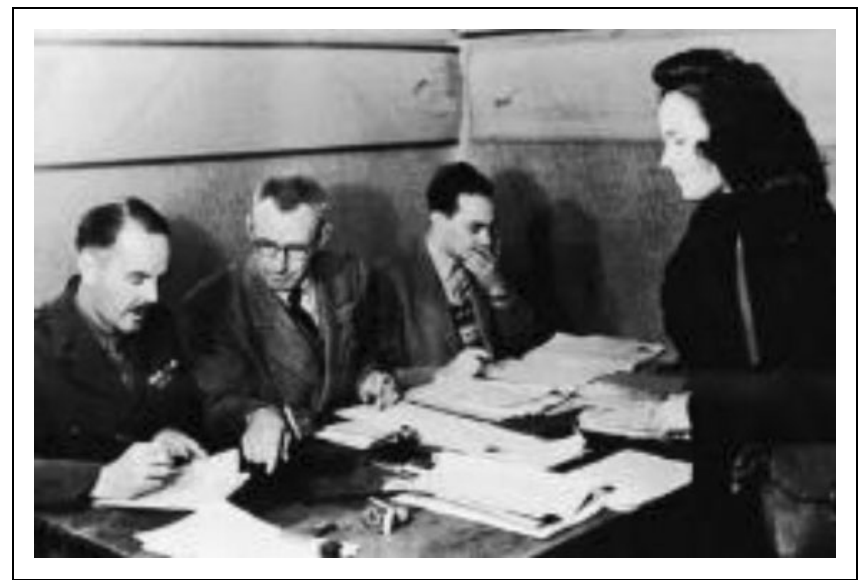

Figure 2. First DP selection team, 1947. Source National Archives of Australia (NAA) AI21 II, 2/1947/35A/IB.

to the concept of European DPs in the best possible light. Initiated by Calwell, it has become known to history as "Calwell's Beautiful Balts" (Balint 2014; Pennay 2007; Persian 2015, 2017; Simic 2014). This campaign comprised a megamarketing strategy that would first acquire a shipload of the "best types" and then market them to a cautious and protective Australia as a taster for what was to follow. Calwell knew that this might well not be easy within the nation's collective psyche of what or who was desirable in its population, and hence workforce, and who valued exclusivity. Additionally, at that time, many Australians had little experience of Europeans and few had travelled outside of Australia. This meant for many then, an encounter with any arrivals other than British would be a novel experience, potentially fraught with suspicion (Pennay 2007). Calwell did not want to contest the logic "head-tohead", he went with it. However, as the initiative unfolded, the anti-humanistic nature of the blatant application of national ideology soon revealed itself.

Instructed by Calwell, recruitment officials travelled to DP camps to interview, identify and recruit those who met the criteria of "best types" for Australia (see Figure 2). They were to handpick a first boatload that could be used as a flagship, so to speak, and one that best communicated the potential human capital that lay waiting in the DP camps (Balint 2014). Harold Grant, a migrant selection officer, explained that choosing suitable candidates was governed by the understanding that "[t]hese were the people that you and I could consort with on Bondi Beach (cited in Balint 2014, p. 107), therefore appealing to a "people like us" notion. This meant those that reflected in their possession the deep symbols that constructed the belief system of a "white only" policy. However, competition existed with other countries, each of whom were eager to ensure that they also accessed the best available. Prospective migrants were sold the idea of Australia being a land of industry and sunshine (Balint 2014). Most of the DPs had little knowledge of Australia, and the language barrier could not have made it easy. Screening involved health checks, assessment of suitability for 


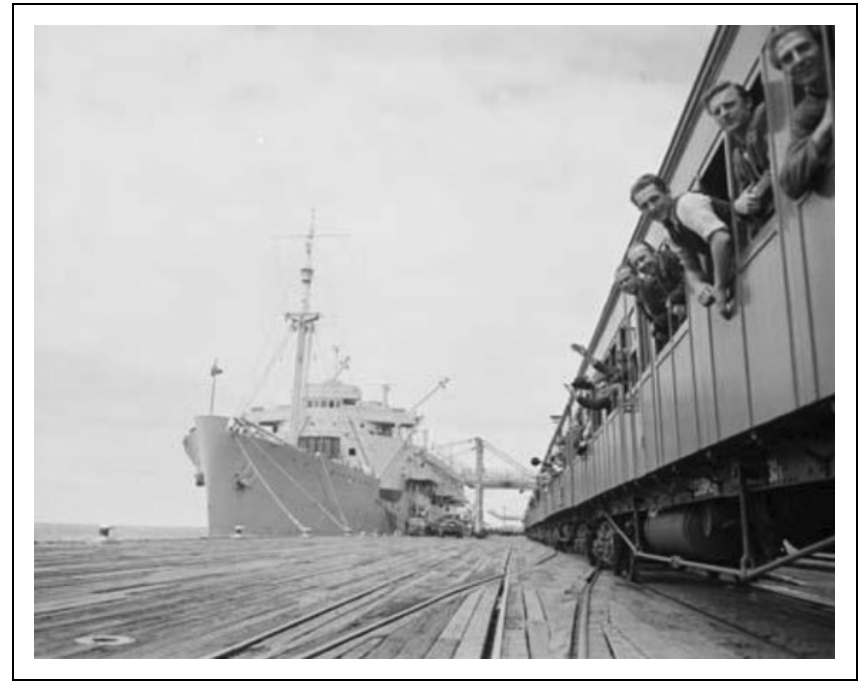

Figure 3. HMAS Kanimbla arrives at Melbourne with the first group of displaced persons (Dec 1947) en route by train to Bonegilla Migrant Camp. Source: NAA A I2I I I, I/1947/3/6.

the type of work required, and somewhat rudimentary checking to ensure there were no Nazi collaborators amongst the prospective emigres. Balint (2014), as commentary on choices available, reports how film director Ron Maslyn Williams, on location in Germany 1948/49, commented, "as one DP put it, from the point of view of many DPs Australia that it is the gambler's shot when attempts to get to America have failed. As one intelligent DP put it to me 'It is Australia or Siberia or starvation"”.

On 7 December, 1947, the ship Kanimbala docked in Melbourne with the first Baltic DPs, to a waiting media (Figure 3). The numbers were reported as follows:

Two months after Australian immigration officials interviewed them in Germany, 839 young Latvians, Lithuanians and Estonians arrived in Melbourne yesterday in the Kanimbla. Eager and jubilant, the migrants will begin a new life in Australia after years of wandering, suffering, hunger and uncertainty. They comprised 112 women and 727 men, nearly all single, all anxious to forget the past in a land where there could be no shadows of their dark and fearful war years. Average age of the migrants is 24 years. One man in an older age group brought his son. Two other transports will follow these newcomers from Germany, one with single men, the other with families and young children. (The Age 8 December 1947 p. 3).

The new arrivals were regarded favorably by those involved with their care. Indeed, the "migrants are splendid types" was the opinion on the 843 Balts of Mr W Ross, Federal Secretary of the Catholic Migration Committee, determined after meeting their transport ship and spending three days at the training and orientation camp at Bonegilla near Melbourne in December, 1947 (see Figures 4 and 5). He described his impressions:

It would be impossible to find a better type of migrant. The men are young, virile, intelligent and eager to work; the women are strong,

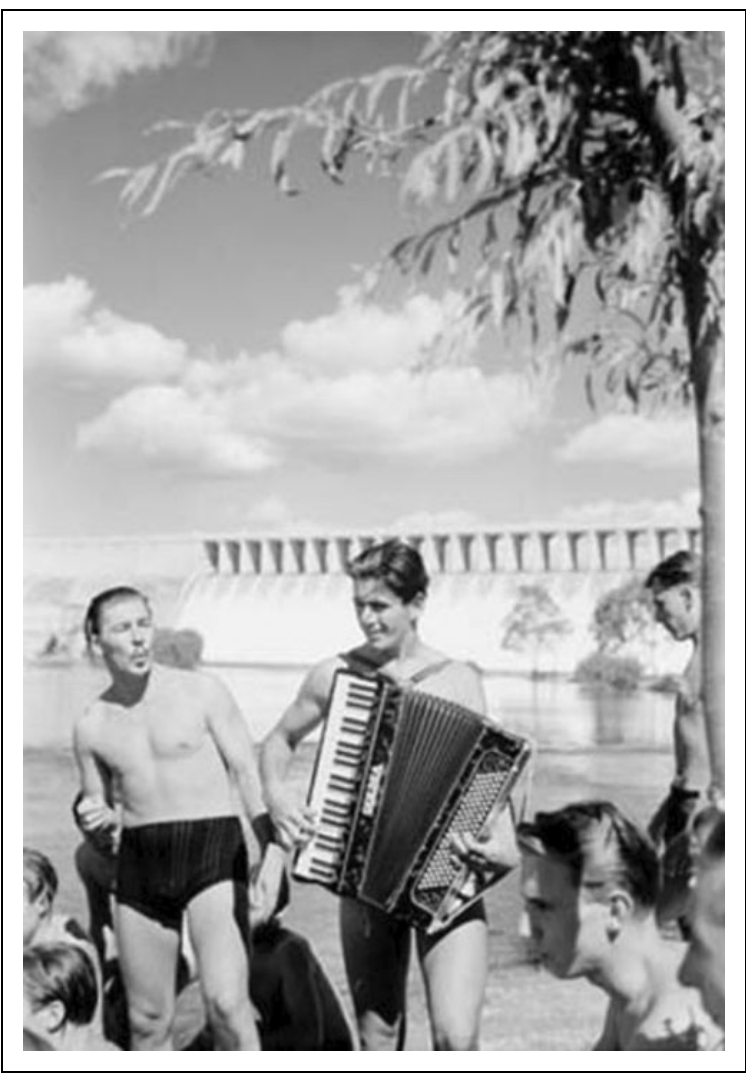

Figure 4. European DPs at Bonegilla Migrant Camp playing piano accordion on the banks of the Hume Weir after swimming. Source NAA: AI2III, I/I947/3/7.

healthy, beautiful. Without exception, the whole group has been tested in the fires of intense physical pain and mental suffering. They will make marvelous citizens (Catholic Weekly 18 December 1947 p. 1).

Calwell was also impressed upon their arrival, causing him to declare that they were "his Beautiful Balts". Their attributes were admirable. The media reported that they were:

attractive, cheery, eager to work and neatly clad. The women had 'surprisingly good complexions and figures'. In smiling they displayed 'splendidly formed white teeth'. The men were suntanned, strong and good humoured. All were supposedly eager to work as labourers or domestics. They were 'particularly good types' (Border Morning Mail, 9 December 1947).

Predicated on displaying to Australians the collective physical beauty and extreme suitability for the type of work needed to reshape Australia, the Beautiful Balts became homogenised as a unique collective "brand". This quality brand, arguably almost Nazi-esque in the physical attributes promoted as most desirable, became a major selling point, aimed at softening attitudes and increasing readiness for further DP arrivals. These Balts, as a sample of DPs for resettlement, held attributes symbolic of quality immigrants for Australia and easily acquired to 


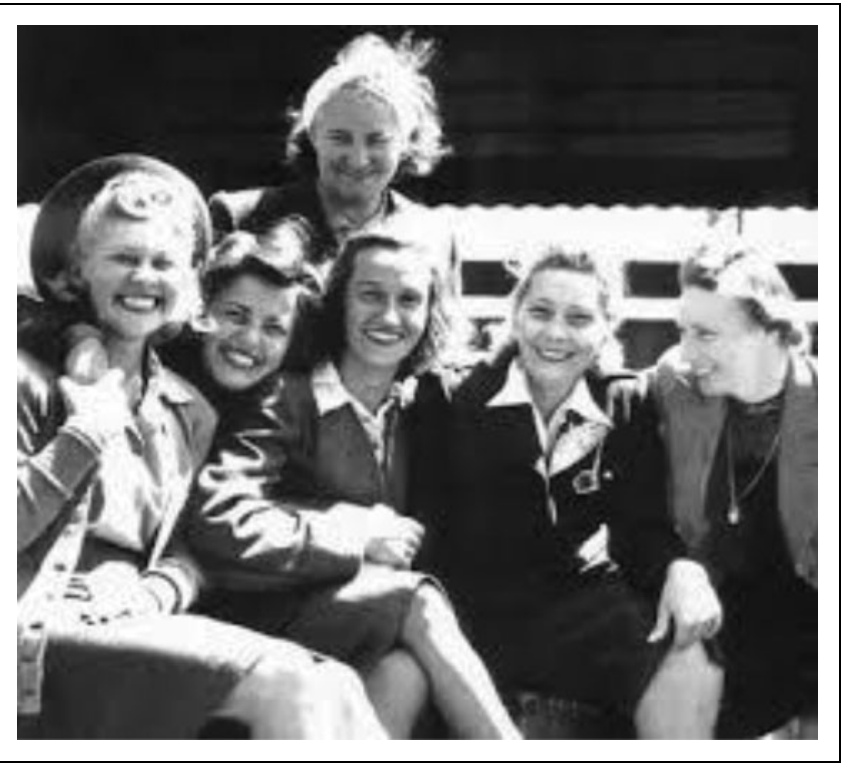

Figure 5. DPs on way from Bonegilla to work as domestics and aides in Melbourne hospitals, 1948. Source: The Sun Newspaper, "Bonegilla Photographs" exhibition.

demonstrate how markets could be provisioned with essential economic labour to provide increased production. Calwell's declaration that a group of European DPs could possess such attributes that Australia has built its immigration policies on (effectively British only) arguably commenced the process of demystification. Taking pains to reassure the Australian people that these DPs were in fact people just like them, Calwell knowingly or unknowingly exposed the Australian people to a rhetoric that demeaned the exclusiveness of the Australian brand. The highlighting of physical attributes such as good figures, white teeth and suntans as attributes that would resonate with Australians as important, further trivialised what it was that a "white only" policy meant in practice. Even more, the sacred attributes or deep symbols that made up the Australian identity could in fact be found in a group of refugees. Another aspect stressed was their strong anti-Communist position, providing further opportunity for Calwell to frame his initiative as a mercy mission from Russian Bolshevik domination (Persian 2015). The Beautiful Balts were also well aware of their responsibilities and the importance of conducting themselves well in their public relations role. Indeed, archival photographs that were used for media dissemination at the time attest to the good-natured and cheerful dispositions in front of the camera.

Perhaps made less clear at the time to the Australian population, was that this first arrival of Balts was to be the "Trojan Horse" of WWII DPs to Australia (Persian 2015). By the late 1940s-1953, 170,000 DPs from Europe were accepted into Australia (Pennay 2007). This included not only those of Baltic origin, and of whom many native born were not blond and blue eyed as promoted, but also DPs from many European nations (Poles, Yugoslavs, Ukrainians, Hungarians, Czechoslovaks, Russians, Germans and Romanians) that made up the fabric

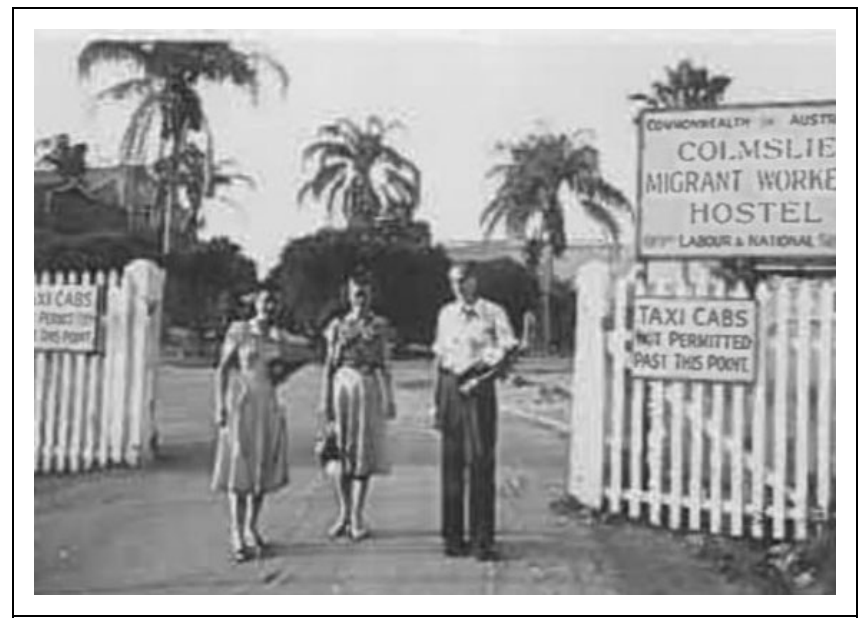

Figure 6. Author's father at gates of Colmslie Migrants Camp, 1949. Source: Author's archives.

of the camps. Callwell insisted that the term migrant not be used, but rather "new Australian" (The Sydney Morning Herald 16 December 1947 p. 9). As "new Australians" (for comparison, existing citizens were now to be called "old Australians"), they were tasked with assimilating, learning the language, adopting Australian ways and one day providing the next generation of Australians. Use of the term "new" Australian also demythologised the narrative of what it took to be an authentic Australian. Although by definition not "old" (sic established) Australians, through frame transformation, the boundaries around that status were loosened by the demands of those in authority so that they were Australian (of whatever elk), but not to be known as migrants. Unfortunately, one outcome of the proliferation of the Beautiful Balts narrative meant it was now indelibly written into the collective Australian memory; so much so that all migrant DPs, irrespective of nationality, were commonly known as "Balts" or "Bloody Balts" (Persian 2015).

\section{"New Australians” as System Challengers}

On arrival to Australia, those working on government utilities and factories (e.g. brickworks for housing schemes) and large infrastructure programmes (rail and road) workers were housed in Migrant Reception Centres (hostels/holding centres/migrant camps, converted military barracks) (see Figures 6 and 7). In the late 1950 s, there were thirty such centres across the states. DPs were contracted for two years, whereupon they were then free to seek other employment. Tolstoy (1950) spells a somewhat dismal picture, claiming that all receiving countries, except the US (which gave DPs "all opportunities"), were interested in cheap labour and the work to which they were allocated was "pitiful" (p. 55) and although they were free to seek other employment at the end of their two year contracted period, there were few options available.

One such example of a large infrastructure project was the Snowy Mountain Hydro Scheme (see Figure 8). This was commenced in 1941 to develop irrigation for farmland and combat 


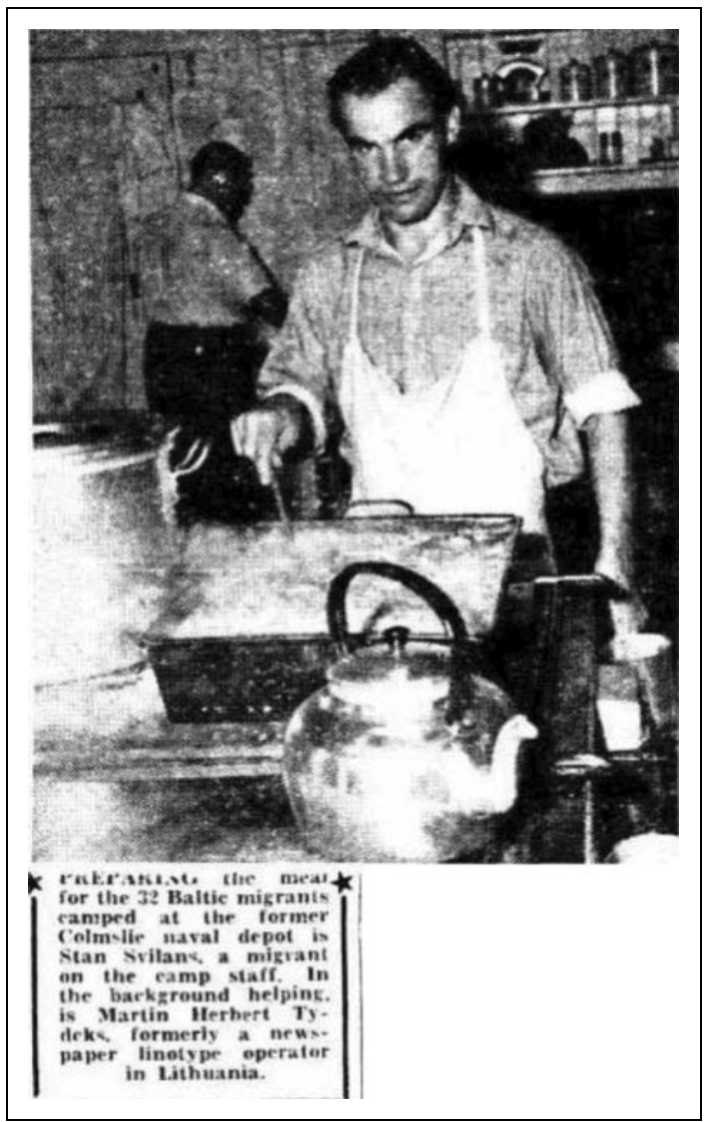

Figure 7. A newspaper article "New Balt Community is Happy Here" shows an image of author's father's friend and fellow camp resident, content in his work in the camp kitchen. Source Brisbane Telegraph, Saturday 15 January 1949, p. 11.

effects of drought. Of the 100,000 workers, 66,000 were DPs who had signed a two-year agreement. Such was the mix of DP nationalities contracted there that the Snowy Mountain Hydro Scheme is suggested as Australia's first multicultural society, occurring years before policy changed to embrace multiculturalism within Australian society (Ashton 2009; Griffin 2003).

The remote location of many of the schemes, new climate, contracted nature of the work and for some schemes, hardship of life in the mountains (especially for those DPs who had come from large European cites) was challenging. Inevitably, conflicts at times erupted between different European nationalities with pre-war existing conflicts (Ashton 2009). Dislocation from their culture and own landscape and sense of place also exacerbated feelings of hardship. For instance, the overwhelming smell of eucalyptus (an Australian native tree) was reported to be a real irritant for many DPs (Ashton 2009). For those contracted to isolated areas, it was difficult to assimilate with "old Australians" as there were few opportunities to mix with non-DPs, meaning that native language and cultural practices predominated. Personal memoirs, recorded in emergent scholarly work (e.g. Persian 2015; Persian 2017), highlight the traumas and difficulties encountered. These included leaving Europe, their inability to contact anyone left

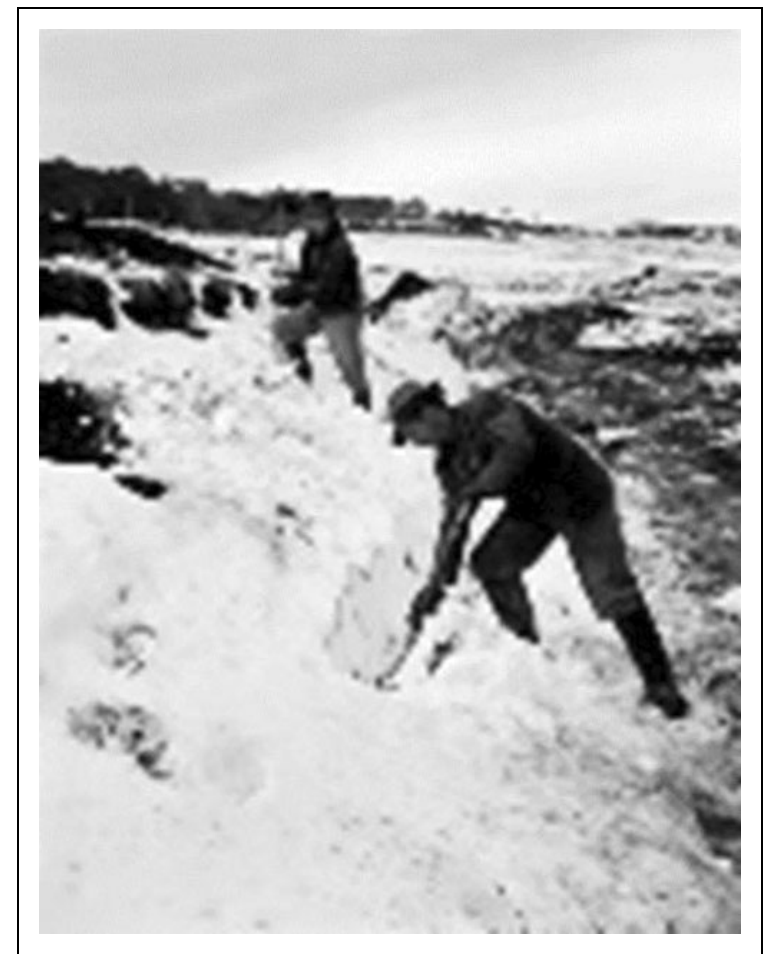

Figure 8. "New Australians" doing road construction between Kiandra and Tumut Ponds for construction of Snowy Mountains Hydro-Electric Scheme, 1950. Source NAA AI I0I6, 354.

at home due to the Soviet communist regime and fear of raising the suspicions of Soviet authorities there, adjusting to a new climate, hard manual work in isolated locations and the sheer difficulties of learning a new language with few opportunities for conversation.

Initially single men were favoured for immigration in light of the type of work schemes labour was required for, much of which was located in isolated or rural areas, where providing accommodation and support for families would be difficult. As Australia emphasised the value of unencumbered male workers this meant DPs were often separated from their families, who remained in DP camps in Europe until they could be reunited (from 1948). For those who were unmarried, there were reduced chances of finding a partner in the near future as few women had been desired for resettlement in the early years, and then were generally employed in the city as domestic workers. This was felt especially acutely as several potentially productive years had been spent in limbo in DP camps. Many single men had also left family behind in the camps only to experience later that marriages had broken down when they had finally managed to arrange transport to Australia for them (Simic 2014).

Assimilation was supported through language classes and the Good Neighbour Programme. The Good Neighbour movement tasked "old Australians" to assist the assimilation of "new Australians" through hosting activities, making them feel welcome and generally becoming good neighbours (see Figures 9 and 10). For the "new Australians" things did not always go well in regard to integration into the marketing system and the 


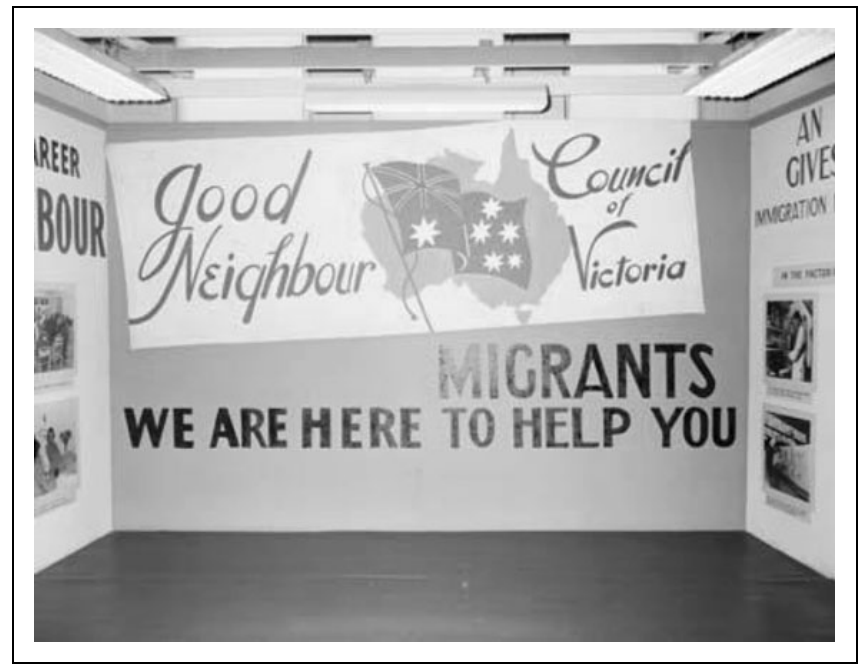

Figure 9. The display of the Good Neighbour Council of Victoria at the Careers Exhibition, July 1956. Source NAA A I I I I, I//956/I9/20.

communities that relied on this system for provision of their own resourcing and successful exchange. Despite the intentions of the government under the Good Neighbour scheme, tensions and resentments occurred (Simic 2014). Trade unions in particular were concerned about the loss of local jobs. Concerns of Nazi infiltration was another genuine concern often raised (Advertiser 13 June 1949 p. 3).

Benefits of having DPs within communities were communicated as them being enriched by cultural benefits through the DPs coming from "ancient" cultures and their spending power in local communities. The Queensland Times reported they:

solved critical labour problems through their assignment to work that had not attracted or held sufficient Australian labour because of its arduous nature and isolated location. For example, the introduction of displaced persons to the sawmilling section of the industry in Victoria 'saved it from coming to a virtual standstill' (Queensland Times 6 June 1949 p. 2).

There is no doubt that the DPs raised productivity significantly, from their allocation to work and locations that were not often favoured by local workers and application to producing good work (Colic-Peisker 2011). The Cairns Post reported DPs were significantly stepping up production through their fine physiques and industrious habits. Mr Holt, (Minister for Immigration 1949-56) is reported saying of the new Australians:

'With regard to rural production', he said, 'in Queensland record sugar crops have been harvested with the aid of displaced persons. It would have been entirely impossible to do this had the labour of European migrants not been available. I have seen some of the men at work in Queensland. They struck me as being of splendid physique. They were working extremely hard under conditions which to many of them, must have been very strange indeed and at times, having regard to the climates of the countries from which they had come, extremely uncomfortable; They were working cheerfully and doing a marvelous job'.

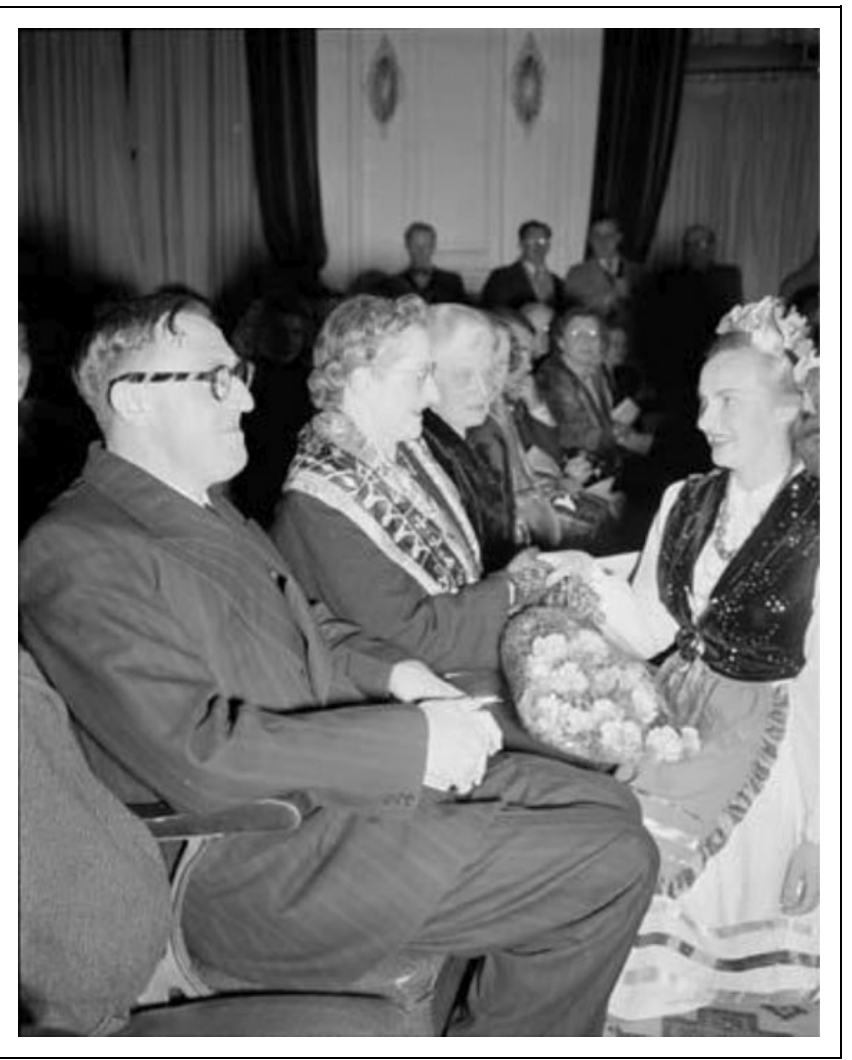

Figure 10. Arthur Calwell and his wife at the Lithuanians Handicraft Exhibition, New Australian Festival, Canberra, 1949. Source NAA Al21II, I/1949/17/5A

The article continued:

Migrant labour had made a substantial contribution to production in Australia in a number of important directions, said Mr. Holt: With their help the production of bricks in New South Wales in November last increased to 32 million, the highest figure since June of 1929. In Victoria, 45 million extra bricks were produced by displaced persons. That was the equivalent of 1800 all brick houses or 3600 veneer houses. (Cairns Post 8 February 1950 p.4).

Initial demystification required further framing through amplification. Messages such as those given above can be compared to the amplification framing process (Benford 1993; Benford and Snow 2000), where messages around outcomes of increased productivity and in some instances saving production from standstill were embellished to detract from other possible meanings and a migrant labour threat might conjure up.

In response to adversarial comments about their participation in the marketing system DPs often exercised their own agency in defending their position. A letter to the Editor written in 1949 captures the feeling of the DPs:

We could not understand why you objected to our employment. One of your anxieties was that we would lower wage standards and displace Australian workers. This is groundless. Can a few Balts displace hundreds of Australian workers, especially when we have 
not Australian citizenship and are not able to seek a job for two years, and when our "lower wages standard" is under the direction of the Labour Department? We have been working at Anchor tin mine, St. Helens, and were welcomed by the miners there. They were glad because more men meant more tin for Australia. Our wages were the same as those of Australian workers for the same work. Why didn't those miners object to us? How many Balts have displaced Australian workers? We don't understand a "trial for three months." This insulted not only us but all Balts in Australia. We come not from a barbarous country but one where culture and living standards, before Communist influence arrived, were not lower than in Australia. We come here as political refugees because we like freedom. As newcomers we will keep away from any policy. Provocation by some people will not be able to disturb our will to do our best for Australia and later to become good lawful Australian citizens. (The Mercury 23 March 1949 p. 3).

The above quotes demonstrate the meso-level conflicts that the new systems challengers met with and responded to. These tensions still resonate with migrants today (see for e.g. Jafari and Goulding 2008). In the initial period, action fields became unstable due to the influx of new actors, whose approach to work was seemingly different from incumbents. With mutual feelings of distrust and frustration between the two actor groups, perpetuation of familiar order as described by Layton (2015) became a focus.

\section{Summary of the Beautiful Balts Campaign Chronology}

A small progressive force within the governance units of Australia's aggregate economic system understood that rapidly changing global political, economic, and socio-cultural conditions have resulted in a significant misfit between the partially closed economic system and the environment. At this point, a strategic rift has occurred: a small task force has separated from the governance units group (Figure 11). This force acted as a catalyst for change by creating a thoroughly designed megamarketing campaign that included primarily a framing process of demystification, as well as other frames to enhance the receptiveness of the system for an input of human resources the system was not accustomed to and break down the concealed mystique that protected the status quo. Thus, a degree of planned disorder has been created, though the influx of new endowment agents, in order to avoid an anticipated future of significant chaos.

Although the campaign is in itself considered ethically reprehensible by some authors (see Balint [2014] and Persian $[2015,2017])$. what is notable is that it was culturally "coded" so that the system did not treat the new input as a "pathogen". Although DPs quickly became an integral part of action fields in the capacity of system challengers, their integration to the system as full-fledged members (i.e. incumbents) was very slow. However, the newly formed sphere of challengers enabled the aggregate system to become more open to the subsequent influx human resources that became a foundation of the modern, more innovative Australian economic system. We now proceed to discussion of our findings.

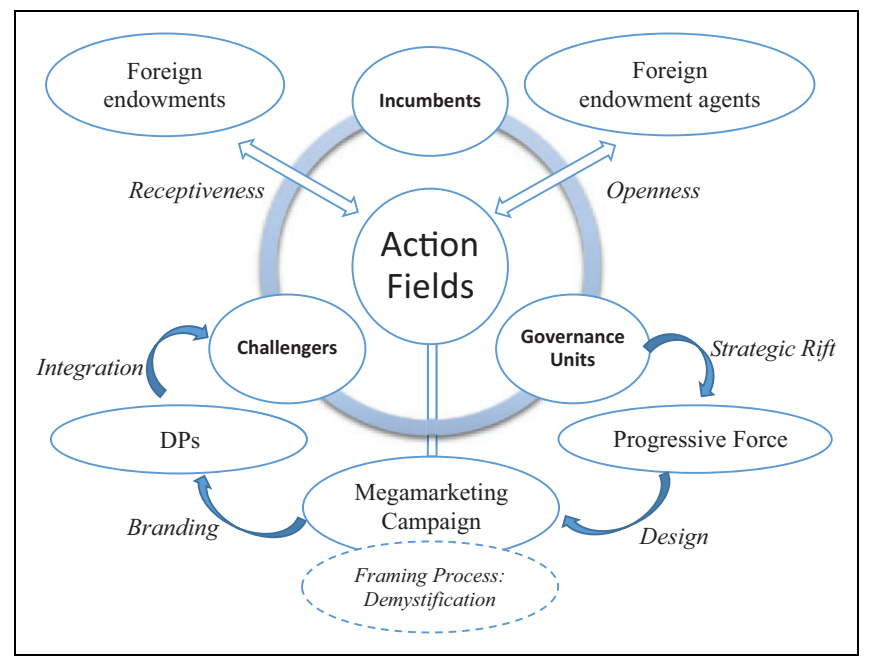

Figure I I. Demystification framework.

\section{Discussion: Openness and Receptiveness of Marketing Systems}

The current research contributes to the general macromarketing agenda of developing a better understanding of the sources of stability and change in marketing systems (Layton 2015) which may help in solving problems such as the migration conundrum. As the historical account of the Beautiful Balts megamarketing campaign indicates, one of the sources of stability can be institutional frames that govern screening the input of "correct" endowments and the desirable owners of such endowments. Such stability may have its cost: the system can lose its adaptiveness in the long-term thereby developing a degree of specific closure.

This research highlights a unique connotation of the concept of openness/closedness of marketing systems. Research so far has discussed general openness of economic systems to environmental resources (Reidenbach and Oliva 1983). However, this research shows that marketing systems can be selectively open for a supposedly "superior" input that fits the purposes of internal meaningfulness, while developing selective closedness toward inputs deemed inferior. This can lead to non-humanistic, privileged, and involuntary structures. Hence, not all marketing systems evolve into open and free exchange milieus. Dominant institutional frames, as seen in the case of Australia's "white only" policies, played a significant role in such demarcation. We observe a specific form of openness which is the receptivity to alien human endowments, specifically, when there are pressing national security needs related to population growth along with humanitarian gestures as reasons for accepting other human beings into the system. The institutional frame that governed the precampaign Australian marketing systems was segregated: foreign endowments were seen not as valuable as Australian or British. The MAS framework (Layton 2015) describes relatively open action fields where participants can contribute endowments of their choice. In contrast, what we observe is that the Australian aggregate marketing system was deeply 
structured, while action fields were organized based on the institutional logic of segregation. Hence, a well-designed megamarketing, including framing that caused enduring action frames to be demythologised, was needed to unsettle the old structure to give the system an impetus for further growth. The contribution of our new framing process, "demystification", elegantly describes the way this was undertaken within a megamarketing context. We believe its foundational application to a historical context does not limit further generalization, particularly to exploration of other marketing systems processes where embedded beliefs and the tenaciousness of deep symbols detract from system progression and the opening up of action fields.

In addition, the dynamics of action fields appears to be more complex than it has been proposed in the literature (Fligstein and McAdam 2012; Layton 2015). Governance units did not only play a straightforward role of the guardians of order. Once these actors realized that the long-term environmental fit of the system was in question, a strategic rift occurred in the group. A small group of change champions separated from the mass and worked to inject a degree of planned disorder so that the system could go through radical but beneficial transformation. The purpose of this subsection of governance units was not to play safe. Rather, they used their system privileges and power to create a significant systemic jolt where old institutional logics, structure, and relationships had to adjust to the new reality. Through the use of appeals to deep symbols upon which the notion of nationhood had evolved and demonstrating how they were also present in the Balts, the government of the day reduced their symbolic meanings from that of sacred to profane. Hence, this specific group became a source of change, who we can call strategic change units. Here, the source of the change was not system challengers as it was previously assumed. In contrast, strategic change units have created a new segment of challengers who worked to make the system more receptive for further changes.

In the context of aggregate marketing systems and their evolution, the role of design cannot be underestimated. In this research, we note that the megamarketing campaign was an interventionist adjustment that was designed to transform the system's institutional logics as well as its structure. Moreover, change was not the result of complex emergent interactions of all system actors. Rather, it was driven by the group who had a broad vision of the system and the requirements for future growth.

\section{Conclusions}

The Beautiful Balts, followed by the migration of thousands more eastern and southern European DPs, was a significant stimulant for change to Australia's aggregate marketing systems. The potential challengers, made more palatable by marketing their physical attractiveness, willingness to work, anti-Communist orientation and "people like us" appeal attributes, was indeed novel for its time, although one could argue physical attributes and stamina for work have been used to sell people to resource marketing systems since the advent of slavery. Yet, it proved instrumental as an interventionist tool, coded in accordance with the institutional logic of the existing marketing system, to create an evolutionary, corrective dynamic that gradually moved the Australian way of life from one of relative isolationism and exclusivity to more openness. It reflected not only the acute need of the day, but also longerterm hopes for post WWII prosperity. This is significant for macromarketing analysis as it demonstrates first how megamarketing centred initially on a small quota of DPs was used by government to address potential fears and resistance for incumbents who had lived in a time of strict immigration control and relative lack of experience of "the other". Second, by changing the existing discourse around foreign endowments through demonstration of possibilities, it acted as a catalyst to alter the makeup of the Australian action fields and hence change the assortment of its labour inputs.

Displacement is a critical ongoing problem for humanity and society at its broadest level. Given the current political climate and refugee issues faced by many countries, understanding the role of macromarketing systems and structures in this, and the potential to impact wellbeing at the societal and ultimately individual level is critical, albeit from a historical standpoint.

Circling back, this research extends the research on marketing systems, megamarketing, institutional logics, and framing processes by introducing a new hitherto undocumented process of (counter)framing. As the case illustrates, demystification requires an approach that at first appears to be against common sense. It is a counterframing tactic with a view of effecting change in marketing systems, which is non-confrontational, being akin to Slavoj Žižek's (2008) recipe for fighting systemic violence. Demystification is underscored by illusory "support" for the negative frame, the act which in itself ends up paradoxically undermining the frame's meaningful coherence. The case of Beautiful Balts is applicable to the migration issues of modernity, where fear of "the other" is instilled in antiimmigration ideologies by various governments and country leaders. Here, as a situation unfolds, the process of demystification can also be observed. Perpetuation of a position that the migrant is unattractive or undeserving can dwell safely in a prevailing ideology until the observable enactment of such a stand, which shatters the original position, occurs. As further example, during 2018, media headlines such as "what zero tolerance really looks like" (CNN18 June 2018) led media articles on the US Government immigration policy that resulted in the separation of families at the Southern US Border. As a result of demystification of what zero tolerance means in reality, an executive order was signed to "keep would be migrant families at the border together" a few days after media coverage of this treatment broke resulting in widespread protest within the US (CNN 20 June, 2018).

Currently, the remaining DPs and their descendants form a significant part of the Australian population, with many strong cultural communities active within Australian centres. Alongside this, the message to assimilate and become "new Australians" has indeed been enacted. For many, keeping traditional cultural practices and language alive and providing 
education of their young in these matters are recognised as beneficial just not for themselves, but as a mechanism to enrich wider society through the vibrancy and richness contributed by diversity in a multicultural society. Eventually, a more open system resulted in more micro formal and informal systems and structures that brought "old" and "new" Australians together and caused them to interact and stabilize marketing system action fields. It was, however, the initial forcing of the macro-environment that served as the main catalyst for change. Tavan (2004) claims that the abolition in 1973 of the White Australia policy and its doctrine was important for truly opening up the pathway to a multi-cultural society. However, the author does caution:

sporadic immigration controversies during the past two decades suggest the residual influence of this doctrine. Some commentators even claim that contemporary conflicts are the legacy of a reform process implemented by political leaders without the knowledge and consent of the Australian people (p. 109).

The application of marketing principles to improve the plight of today's refugee migrants is emergent in the marketing literature (see Nasr and Fisk [2018] for their conceptual work on Transformative Services Research to aid the global refugee migrant crisis. See also Finsterwalder [2017] for recommended future research on the interface between refugee actors and residing actors from a service ecosystem perspective).

Krisjanous (2014) notes that timing of the emergence of earliest roots of social marketing extend further back than much contemporary literature gives credit to. In this regard, we also acknowledge that a macro-social marketing lens could be used to examine the Beautiful Balts event as a possible manoeuvre by the Australian Government to create a more open beneficent refugee macro environment post WWII. However, the Beautiful Balts campaign is not without its criticisms in current contemporary analysis. These criticisms include the exploitative and manipulative nature of the strategy, both toward the DPs and the Australian people.

While we have privileged the evidence that supports the effectiveness of this campaign in opening up the market for post-war Australia, we do acknowledge that such criticisms as may be found in works by authors such as Balint (2014) and Persian $(2015,2017)$. Here we must also argue that our analysis leads to a conclusion that the Beautiful Balts campaign was not designed primarily as a "social good" product, i.e. to aid the global refugee crisis of the day and alleviate human suffering of migrants. Within this context, the resulting transformation of marketing systems from the Australian Government's desire to open up labor markets was the dominant force for action. Ultimately, this did influence the shaping of individual and Australian societal wellbeing by moving toward greater inclusiveness of ethnic diversity. However, it was not intended at the time. So in contrast to any macromarketing ethos of "doing well by doing good", what is documented here is positive good (ultimate acceptance of more ethnic diversity) as an unsought byproduct of a commercial objective (an influx of labor).
Nevertheless, terminology such as activism and social engineering is increasingly used in discussions around the boundaries of macro-social marketing to determine what it is and is not, even though these terms seem antithetical to all that is good about marketing (Kennedy and Parsons 2014). These actions, once considered off limits for marketers, are beginning to be reconciled to macro-social marketing (see Kennedy and Parsons 2014). Hence, the examination of the Beautiful Balts story from a macro, meso and micro level social marketing perspective is a potential future avenue for research. This could lead to a better understanding of the boundaries of megamarketing, macro-social marketing and "social engineering".

\section{Acknowledgments}

The authors would like to thank the Editor and anonymous reviewers for their comments and guidance on earlier versions of this paper.

\section{Declaration of Conflicting Interests}

The author(s) declared no potential conflicts of interest with respect to the research, authorship, and/or publication of this article.

\section{Funding}

The author(s) received no financial support for the research, authorship, and/or publication of this article.

\section{ORCID iD}

Jayne Krisjanous (D) http://orcid.org/0000-0002-7881-419X

Djavlonbek Kadirov (D) http://orcid.org/0000-0001-7618-6903

\section{References}

Aaronovitch, David (2015), "We must Discover the Humanity of 1945," The Times, September, 3, (accessed February 10, 2018), [available at: https://www.thetimes.co.uk/article/we-must-redis cover-the-humanity-of-1945-sznzj27kb9x].

Advertiser (1949), "Allegations over DPs Nonsense" 13 June, 3.

Alderson, W. (1957), Marketing Behavior and Executive Action: A Functionalist Approach to Marketing. Homewood, IL: Richard D. Irwin.

Anderson, V. (2003), "A Relational Concept of Race in African American Religious Thought," Nova Religio: The Journal of Alternative and Emergent Religions, 7 (1), 28-43.

Ashton, Paul (2009), "The Birthplace of Australian Multiculturalism? Retrospective Commemoration, Participatory Memoralisation and Official Heritage," International Journal of Heritage Studies, 15 (5), 381-98.

Ashutosh, I. and A. Mountz (2011), "Migration Management for the Benefit of Whom? Interrogating the Work of the International Organization for Migration," Citizenship Studies, 15 (01), 21-38.

Balint, Ruth (2014), "Industry and Sunshine: Australia as Home in the Displaced Persons' Camps of Postwar Europe," History Australia, 11 (1), 102-27.

Bem, Kazimierz, Nina Field, Nic Maclellan, Sarah Meyer, Tony Morris, and Manus Island Nauru (2007), A Price Too High: The Cost of Australia's Approach to Asylum Seekers. Australia: Oxfam.

Berger, Joseph A. (1947), "Displaced Persons: A Human Tragedy of World War II," Social Research, 14 (1947), 45-58. 
Benford, R. (1987), "Framing Activity, Meaning, and Social Movement Participation: The Nuclear Disarmament Movement," PhD thesis, University of Texas, Austin, TX.

Benford, Robert D. and David A. Snow (2000), "Framing Processes and Social Movements: An Overview and Assessment," Annual Review of Sociology, 26 (1), 611-39.

Benford, Robert D. (1993), "Frame Disputes within the Nuclear Disarmament Movement," Social Forces, 71 (3), 677-701.

Berbrier, Mitch (1998), “"Half the Battle”: Cultural Resonance, Framing Processes, and Ethnic Affectations in Contemporary White Separatist Rhetoric," Social Problems, 45 (4), 431-50.

Border Morning Mail (1947) 9 December.

Carpenter, Inta Gale (2017), "Folklore as a Source for Creating Exile Identity among Latvian Displaced Persons in Post-World War II Germany," Journal of Baltic Studies, 48 (2), 205-33.

Cairns Post (1950), “Migrants' Valuable Work Mr. Holt's Review (From Our Special Representative," Wednesday 8 (February), 4.

Catholic Weekly (1947), "Migrants Are Splendid Types: 853 Balts Are Vanguard of D.P.'S Expected Next Year,” Thursday 18 (December), 1.

CNN (2018), "Trump Signs Order to Stop Family Separations," (accessed June 21, 2018) [available at: https://edition.cnn.com/ 2018/06/20/politics/trump-separation-action-immigration/index. html].

CNNMoney (2018), "What Zero Tolerance Really Looks Like," (accessed June 21, 2018) [available at: http://money.cnn.com/ video/news/2018/06/18/border-separation-reporters-notebookorig.cnnmoney/index.html].

Cohen, G. Daniel (2008), "Between Relief and Politics: Refugee Humanitarianism in Occupied Germany 1945 - 1946," Journal of Contemporary History, 43 (3), 437-49.

Colic-Peisker, Val (2011), "'Ethnics' and 'Anglos' in the Labour Force: Advancing Australia Fair?” Journal of Intercultural Studies, 32 (6), 637-54.

Copland, Douglas (1951), “Australian Development and Immigration," International Labor Review, 63 (6), 633-56.

Davidson, Helen (2016). "Offshore Detention: Australia's Recent Immigration History a 'Human Rights Catastrophe," Guardian, (accessed February 20, 2018) [available at: https://www.theguar dian.com/australia-news/2016/nov/13/offshore-detention-nauruimmigration-history-human-rights].

Eisenhardt, Kathleen M. (1989), "Building Theories from Case Study Research," Academy of Management Review, 14 (4), $532-50$

Eisenhardt, Kathleen M. and Melissa E. Graebner (2007), “Theory Building from Cases: Opportunities and Challenges," Academy of Management Journal, 50 (1), 25-32.

Farley, Edward (1996), Deep Symbols: Their Postmodern Effacement and Reclamation. UK: Bloomsbury Publishing.

Finsterwalder, Jörg (2017), "Refugee Influx: Repercussions and Research Agenda for Service Scholars," Journal of Retailing and Consumer Services, 37 (Jul 1), 177-81.

Fleay, Caroline and Sue Hoffman (2014), "Despair as a Governing Strategy: Australia and the Offshore Processing of AsylumSeekers on Nauru," Refugee Survey Quarterly, 33 (2), 1-19.
Fligstein, (2001), The Architecture of Markets: An Economic Sociology of Twenty-first Century Capitalist Societies. Princeton, NJ: Princeton University Press.

Fligstein, Neil and Doug McAdam (2012), A Theory of Fields. Oxford, UK: Oxford University Press.

Fox, Grace (1950), “The Origins of UNRRA,” Political Science Quarterly, 65 (4), 561-84.

Gemie, Sharif, Laure Humbert, and Fiona Reid (2012), Outcast Europe: Refugees and Relief Workers in an Era of Total War 1936-48. London, UK: International Publishing Group Continuum.

Goffman, Erving (1974), Frame Analysis: An Essay on the Organization of Experience. Cambridge, MA: Harvard University Press.

Griffin, Grahame (2003), "Selling the Snowy: The Snowy Mountains Scheme and National Mythmaking," Journal of Australian Studies, 27 (79), 39-49.

Guardian, the (2018), "Tony Abbott Repeats Claim Immigration Cut Will Improve Quality of Life,” (accessed February 20, 2018) [available at: https://www.theguardian.com/australia-news/2018/ feb/19/tony-abbott-renews-push-to-cut-migration-to-improve-qual ity-of-life].

Hatton, Timothy (2017), "Refugees and Asylum Seekers, the Crisis in Europe and the Future of Policy," Economic Policy, 32 (91), 447-96.

Humphreys, Ashlee (2010), "Megamarketing: The Creation of Markets as a Social Process," Journal of Marketing, 74 (2), 1-19.

Jafari, Aliakbar and Christina Goulding (2008), "We are not Terrorists!" UK-based Iranians, Consumption Practices and the "Torn Self," Consumption, Markets and Culture, 11 (2), 73-91.

Kadirov, Djavlonbek and Richard J. Varey (2011), "Symbolism in Marketing Systems," Journal of Macromarketing, 31 (2), 160-71.

Kadirov, Djavlonbek and Richard J. Varey (2014), "Wisdom as Excellence in Commitment to Humanistic Marketing Practice," in Humanistic Marketing, R. J. Varey and M. Pirson, eds. London, UK: Palgrave Macmillan.

Kennedy, Ann-Marie (2016), "Macro-social Marketing," Journal of Macromarketing, 36 (3), 354-65.

Kennedy, Ann-Marie and Andrew Parsons (2014), "Social Engineering and Social Marketing: Why is One "Good" and the Other "Bad"," Journal of Social Marketing, 4 (3), 198-209.

Kennedy, Stetson (2011), The Klan Unmasked: With a New Introduction by David Pilgrim and a New Author's Note. US: University of Alabama Press.

Kotler, Philip (1986), "Megamarketing," Harvard Business Review, 64 (2), 117-24.

Krisjanous, Jayne (2014), "Examining the Historical Roots of Social Marketing through the Lights in Darkest England Campaign," Journal of Macromarketing, 34 (4), 435-51.

Layton, Roger A. (2015), "Formation, Growth, and Adaptive Change in Marketing Systems," Journal of Macromarketing, 35 (3), 302-19.

Levitt, Steven D. and Stephen J. Dubner (2006), Freakonomics: A Rogue Economist explores the Hidden Side of Everything. UK: Penguin.

Lowe, Kevin (2013), Savage Continent: Europe in the Aftermath of World War II. London: Viking.

Murphy Henry (1952), "The Assimilation of Refugee Immigrants in Australia,” Population Studies, 5 (3), 179-206. 
Nasr, Linda and Raymond P. Fisk (2018), "The Global Refugee Crisis: How can Transformative Service Researchers Help?" The Service Industries Journal. doi: 10.1080/02642069.2018.1445224 (published online).

National Archives of Australia (NAA), "Immigration Records - Fact sheet 227," (accessed February 2, 2018) [available at: http://www. naa.gov.au/collection/fact-sheets/fs227.aspx].

National Library of Australia (TROVE) (accessed February 2, 2018) [available at: https://trove.nla.gov.au/].

Pennay, Bruce (2007), Calwell's Beautiful Balts: Displaced Persons at Bonegilla. Wodonga, VIC: Parklands Albury-Wodonga.

Persian, Jayne (2015), “'Chifley Liked Them Blond': DP Immigrants for Australia," History Australia, 12 (2), 80-101.

Persian, Jayne (2017), Beautiful Balts: From Displaced Persons to New Australians. Australia: NewSouth.

Queensland Times (1949), "Many Displaced Persons Benefiting Country Areas Canberra," Monday 6 (June), 2.

Reidenbach, R. Eric and Terence A. Oliva (1983), "Toward a Theory of the Macro Systemic Effects of the Marketing Function," Journal of Macromarketing, 3 (2), 33-40.

Reidenbach, R. Eric and Terence A. Oliva (1981), "General Living Systems Theory and Marketing: A Framework for Analysis," The Journal of Marketing, 45 (4), 30-37.

Reuters (2018), "Hungary Submits Anti-immigration 'Stop Soros' Bill to Parliament," (accessed February 20, 2018) [available at: https://www.reuters.com/article/us-hungary-soros-law/hun gary-submits-anti-immigration-stop-soros-bill-to-parliamentidUSKCN1FY1JE].

Scott, W. Richard (2014), Institutions and Organizations: Ideas, Interests and Identities. Thousand Oaks, CA: Sage.

Shephard, Ben (2010), The Long Road Home: The Aftermath of the Second World War. London: Random House.

Simic, Zora (2014), "Bachelors of Misery and Proxy Brides: Marriage, Migration and Assimilation, 1947-1973," History Australia, 11 (1), 149-74.

Sredl, Katherine C., Clifford J. Shultz, and Ružica Brečić (2017), "The Arizona Market: A Marketing Systems Perspective on Pre-and PostWar Developments in Bosnia, with Implications for Sustainable Peace and Prosperity," Journal of Macromarketing, 37 (3), 300-16.

Storer, Des (1984), "Migrant Workers in Victoria: Trends in Employment and Segmentation," Journal of Intercultural Studies, 5 (3), 5-35.

Smyth, G. (2009), "Deep Symbols and Mythic Imagination in the Hermeneutics of Creation Text," Islam and Christian-Muslim Relations, 20 (3), 227-45.
Tavan, G. (2004), “The Dismantling of the White Australia Policy: Elite Conspiracy or Will of the Australian People?" Australian Journal of Political Science, 39 (1), 109-25.

The Age (1947), "Kanimbla Brings: 839 Balt Migrants First Displaced Persons Arrive", Monday 8 (December), 3

The Mercury (1949), "Letters Of The Editor Balts' Open Letter," Wednesday 23 (March), 3.

The Mercury (1949), "Minister Says Resurgent Japan, Red China Dangers Facing Australia," Thursday 13 (October), 11.

The Sydney Morning Herald (1947), "Minister Dislikes Use of Word "Migrant"”, Tuesday 16 (December), 9.

Thomas, Patricia Ann (2016), "Emigration and Imperial Business: The New Zealand Company Brand 1839-1841," Journal of Historical Research in Marketing, 8 (2), 284-307.

Tolstoy, Alexandra (1950), “The Russian DPs,” Russian Review, 9 (1), 53-58.

Warwick Daily News (1949), "Must Populate to Avert Dangers Facing Nation," Thursday 13 (October), 1.

Wooliscroft, Ben and Alexandra Ganglmair-Wooliscroft (2017), "Marketing Systems' Contributions to Society: Past, Present and Potential," Call for Papers for a Special Issue of the Journal of Macromarketing.

Žižek, S. (2008), Violence: Six Sideway Reflections. New York: Picador.

\section{Author Biographies}

Jayne Krisjanous (PhD University of Victoria, Wellington) is a senior lecturer at the School of Marketing and International Business, Victoria University of Wellington, New Zealand. Jayne's research interests include social marketing, healthcare marketing and historical research in marketing. Jayne's research has been published in journals such as Journal of Macromarketing, Journal of Services Marketing. Journal of Nonprofit \& Public Sector Marketing, and Psychology \& Marketing. Jayne's father, Zanis Krisjanovs, was a Latvian DP who came to Australia as part of the earliest contingents of Baltic DPs from Europe post WWII.

Djavlonbek Kadirov ( $\mathrm{PhD}$, University of Waikato) is a marketing lecturer at the School of Marketing and International Business, Victoria University of Wellington, New Zealand. Djavlonbek's research interests include marketing systems theory, symbolism in marketing systems, sustainable marketing, and marketing morality. His research has appeared in journals such as the Journal of Macromarketing, Journal of Marketing Management, Journal of Business Research, Journal of Brand Management and Consumption Markets \& Culture. Djavlonbek (along with Richard Varey and Ben Wooliscroft) is the winner of the George Fisk Award for the Best Conference Paper at the 2013 Macromarketing Conference. 